MILAN KOLJANIN, naučni saradnik

Institut za savremenu istoriju

UDK 94(497.11)"1941/1944"

Beograd, Trg Nikole Pašića 11

351.741(497.11)"1941/1944"

\title{
STRUKTURA I DELOVANJE POLICIJE NACISTIČKE NEMAČKE U OKUPIRANOJ SRBIJI 1941-1944*
}

\begin{abstract}
APSTRAKT: U članku su prikazani struktura i delovanje policije nacističke Nemačke na nemačkom okupacionom području u Srbiji. Data je i struktura celokupne nemačke policije posle dolaska Hitlera na vlasti $i$ njena transformacija $u$ skladu sa strateškim ciljevima nacističke države. I u Srbiji se pokazalo da su nemačke policijske službe imale glavnu ulogu u sprovođenju ciljeva okupacije i u represivnim merama prema stanovništvu. Rad je napisan na arhivskim i objavljenim izvorima i odgovarajućoj literaturi.
\end{abstract}

Ključne reči: Nacistička Nemačka, policijske službe, Srbija, okupacija, represija, Holokaust

Za razumevanje uloge nemačke policije na okupiranim područjima Evrope, pa i na nemačkom okupacionom području u Srbiji, potrebno je nešto reći o karakteru i organizaciji te centralne represivne ustanove nacističke Nemačke. Treba imati u vidu da je organizaciona šema nemačke policije primenjivana i na nemačkim policijskim ustanovama u okupiranim zemljama, uz izvesne specifičnosti.

Nemačka policija kakvu je vidimo na početku Drugog svetskog rata i u okupiranoj Srbiji nastala je spajanjem nekoliko posebnih policijskih ustanova, koje su do tada bile donekle i konkurentske. Radi se o spajanju policijskih i bezbednosnih službi Nacionalsocijalističke radničke partije Nemačke (Nationalsozialistische deutsche Arbeiterpartei - NSDAP) i državnih policijskih službi, koje su u međuvremenu takođe došle pod kontrolu nacističke partije. Spajanje i srastanje državnih i parijskih ustanova je, inače, karakteristika totalitarnih država. ${ }^{1}$

Nacistička Nemačka je i u Jugoslaviji u drugoj polovini 1930-ih godina pojačala obaveštajnu aktivnost. Stvorene su dve jake i dobro organizovane obaveštajne mreže - vojna (Abwehr) i partijsko-policijska u okviru Glavne uprave

\footnotetext{
${ }^{*}$ Rad je deo projekta Srpsko društvo u jugoslovenskoj državi u 20. veku-Između demokratije i diktature (177016) koji finansira Ministarstvo prosvete i nauke Republike Srbije.

${ }^{1}$ Hana Arent, Izvori totalitarizma, Beograd 1998, 403-407.
} 
bezbednosti Rajha (RSHA) čiji su centri bili u Austriji (od Anšlusa 12. marta 1938. ona je bila Ostmark Velikonemačkog rajha) u Beču i Gracu. Obaveštajne mreže, pre svega mreža Glavne uprave bezbednosti, bile su ujedno i začetak aparata koji će sprovoditi „rešavanje jevrejskog pitanja“ u Jugoslaviji posle aprila 1941. Neke od ključnih ličnosti iz ovog aparata u Jugoslaviji su se pojavile već u drugoj polovini 30-ih godina.

U stvaranju nemačke obaveštajne mreže u Jugoslaviji nisu bili više odlučujući razlozi ideološke srodnosti nego političke koristi. U tom pogledu je vojna obaveštajna služba bila mnogo manje vezana obzirima nego partijsko-policijski obaveštajni aparat Glavne uprave bezbednosti. Ipak, i u njoj je sve više usvajan pragmatičan princip korisnosti, a ne porekla i ideološkog opredeljenja saradnika. ${ }^{2}$ I pored rivalstva nemačke vojne obaveštajne službe i policijsko-bezbednosnog aparata, i sukoba njihovih prvih ličnosti admirala Vilhelma Kanarisa (Wilhelm Canaris) i SS-generala Rajnharda Hajdriha (Reinchard Heydrich), obe obaveštajne službe su u Jugoslaviji odlično sarađivale, što će se nastaviti i posle Aprilskog rata 1941 .

U vreme vlade Milana Stojadinovića uspostavljeni su bliski kontakti i saradnja jugoslovenske i nemačke policije. Milan Aćimović i Rajnhard Hajdrih potpisali su 1938. godine tajni sporazum o razmeni iskustava u borbi protiv komunizma i sprečavanju ustaške terorističke delatnosti. U okviru te saradnje predstavnik jugoslovenske policije je otišao u Berlin, a u Beograd je stigao funkcioner Gestapoa SS-major Hans Helm. ${ }^{3}$ Kao „,policijski oficir za vezu“ (,policijski ataše") on je razvio širok obaveštajni rad, naročito u policijskom aparatu prestonice, u Upravi grada Beograda. ${ }^{4}$ U Glavnoj upravi bezbednosti Rajha Uprava VI bila je zadužena za rad u inostranstvu. Referat E 3 ove uprave bavio se Jugoslavijom, a na njegovom čelu je od kraja 1940. bio SS-major Vilhelm Bajsner (Wilhelm Beissner).

Septembra 1939. u Jugoslaviju je upućen SS-major Karl Kraus, opunomoćenik Uprave VI, koji je kamufliran u Nemačkom saobraćajnom birou (Verkehrsbureau), a zatim u nemačkom poslanstvu kao ,privredni savetnik“. Kraus je stvorio glavni obaveštajni punkt za celu Jugoslaviju i usko je sarađivao sa drugim nemačkim obaveštajnim organima oslanjajući se naročito na militarizovanu organizaciju nemačke nacionalne manjine (folksdojčera) Kulturbund i njegove rukovodioce dr Jozefa-Sepa Janka i dr Jakoba Avendera. Pripadnici Zbora Dimitrija Ljotića postali su takođe važan oslonac Krausove obaveštajne mreže u kojoj je bio i niz ličnosti iz političkog, privrednog i javnog života, kao i iz državnog aparata. Krausov zamenik bio je Alfred Nasenštajn (Nassenstein), koji je stvorio

\footnotetext{
${ }^{2}$ Nemačka obaveštajna služba, Beograd 1955, knj. II, 601-609 (dalje: NOS).

${ }^{3}$ Istorijski arhiv Beograda (IAB), fond Uprava grada Beograda (UGB), Istražni predmet Dragomira Jovanovića Dragog, 2-4, 120-121.

${ }^{4}$ NOS, knj. II, 175-195. Od posebne važnosti bilo je angažovanje visokih policijskih funkcionera Milana Aćimovića i Dragomira-Dragog Jovanovića. Krajem 1938. i početkom 1939. Aćimović je bio ministar unutrašnjih poslova u vladi M. Stojadinovića do njenog pada.
} 
obaveštajnu mrežu u Zagrebu. Berlinska Uprava VI je novembra 1940. u Zagreb poslala SS-poručnika Rudolfa Koba koji je direktno njoj podnosio izveštaje, a ne Krausu. Kob će posle Aprilskog rata postati glavni opunomoćenik ove uprave za Nezavisnu Državu Hrvatsku. U Službi bezbednosti prema Jugoslaviji je najaktivnije delovao njen odsek u Gracu. U jesen 1939. u njemu je stvoren poseban centar za službu u inostranstvu, referat VI, koji je bio u okviru VI uprave RSHA u Berlinu. $^{5}$

$\mathrm{Na}$ čelu razgranate mreže nemačke vojne obaveštajne službe u Jugoslaviji bio je pukovnik Rudolf Tusen (Toussaint), nemački vojni ataše, sa kojim je usko sarađivala posebna „Ratna organizacija Jugoslavija“ Abvera. I vojna obaveštajna služba se u velikoj meri oslanjala na folksdojčere među kojima će se regrutovati pripadnici obaveštajno-diverzantske „Organizacije Jupiter“. Ona će odigrati značajnu ulogu u Aprilskom ratu 1941. I među Tusenovim saradnicima biće neki koji će dobiti svoje mesto u „konačnom rešenju jevrejskog pitanja“ u Srbiji. ${ }^{6}$

Posle dolaska Hitlera na vlast izuzetno je ojačala propaganda kod svih Nemaca izvan Rajha pa i kod jugoslovenskih folksdojčera. Propagandno delovanje na nacionalsocijalističkim principima postalo je deo državne politike matične zemlje, što joj je davalo posebnu težinu tim pre što su njime ubrzo obuhvaćene i brojne nemačke zajednice u drugim evropskim (i vanevropskim) zemljama. Treba imati u vidu da je u nemačkim imperijalnim planovima folksdojčerima bila namenjena posebno važna uloga i na njih se računalo kao sa „rasnim jezgrom“ $u$ „,novom poretku naroda“" na Jugoistoku.

Nemačka nacionalna manjina u jugoslovenskoj državi brojala je nešto preko pola miliona pripadnika. Najvećim delom je živela na području Banata, Bačke, istočnog Srema i istočne Slavonije, odnosno u krajevima u blizini Dunava gde su planski naseljavani od početka 18. veka. Posle Nagodbe 1867. i oni su bili izloženi snažnoj mađarizaciji u Ugarskoj, posebno preko prosvetnih ustanova. Novostvorena Kraljevina Srba, Hrvata i Slovenaca je podsticala organizovanje i nacionalno osvešćivanje folksdojčera da bi se suprotstavila mađarskom iredentizmu. ${ }^{8}$ Ubrzo se pokazalo da je to bio mač sa dve oštrice.

Centralna ustanova domaćih Nemaca od osnivanja 1920. bio je Švapskonemački kulturni savez (Schwaebisch-Deutscher Kulturbund), koji će 30-ih godina od kulturne prerasti u političku organizaciju. Mladi, u nacističkom duhu školovani folksdojčeri, poznati kao „Obnovitelji“, kao što su bili Branimir Altgajer

${ }^{5}$ Isto, $433-467$.

${ }^{6}$ NOS, knj. II, 371, 562-563.

${ }^{7}$ Milan Ristović, Nemački 'novi poredak' i jugoistočna Evropa 1940/41-1944/45. Planovi o budućnosti i praksa, Beograd 1991, 95-114; videti i: Akiku Shimizu, Die deutsche Okupation des serbischen Banats 1941-1944 unter besonderer Beruecksichtigung der deutschen Truppen in Jugoslawien, Muenster 2003, 26-33.

${ }^{8}$ Zoran Janjetović, Deca careva, pastorčad kraljeva. Nacionalne manjine u Jugoslaviji 1918-1941, 39-61; Љубодраг Димић, Културна политика у Краљевини Југославији 19181941, трећи део, Политика и стваралаштво. Београд 1997, 9. 
(Altgayer), Jakob Avender (Awender) i Jozef-Sep Janko postepeno su preuzeli Kulturbund koji je krajem 1940. godine okupljao 95\% jugoslovenskih Nemaca. To je postala ideološki i politički monolitna, militarizovana organizacija pod komandom centralne nacističke ustanove za Nemce izvan Rajha (Volksdeutsche Mittelstelle). Članstvo Kulturbunda će odigrati ulogu „pete kolone“ u vojničkom slomu Jugoslavije i biti jedan od oslonaca za organizovanje „novog poretka" u njoj. ${ }^{9}$

Na novu misiju „izabranog naroda“ na Jugoistoku folksdojčere je upućivalo veličanje i mitologizovanje uloge Nemaca kao spasilaca Evrope od turske najezde. Ideološki i politički nacionalsocijalistička Nemačka se javljala kao baštinik istorijske uloge Dvojne monarhije, ali sada kao predvodnik celokupnog Nemstva u njegovoj novoj misiji. Ovu ulogu umnogome je personifikovao slavni vojskovođa Evgenije Savojski čiji kult će posebno doći do izražaja posle Aprilskog rata 1941. i okupacije Srbije. ${ }^{10}$ Nacistička indoktrinacija domaćih Nemaca ostvarivana je ne samo putem štampe, nego i drugim kanalima koji su bili uglavnom van kontrole vlasti. Školovanje i razni kursevi u Nemačkoj, propagandni materijal (brošure, knjige, pamfleti) koji je odande stizao, predavanja, neformalni kontakti pokazali su se kao veoma efikasan metod za ideološko ujedinjavanje svih Nemaca u čemu je važno mesto imala i borba protiv „Svetskog Jevrejina“. Liberalni novosadski list Dan je doneo vest da je petnaest učitelja iz Nemačke svoju posetu Jugoslaviji februara 1936. iskoristilo za predavanja po nemačkim selima u kojima su veličani Hitler i nacionalsocijalizam. ${ }^{11}$

I pre počeka rata, a naročito posle septembra 1939, pojedinci i grupe jugoslovenskih Nemaca odlazili su i Nemačku i kao dobrovoljci su pristupali jedinicama SS-a i oružanih snaga (Vermahta). Prema novinskom članku rukovodioca nemačke narodne grupe u NDH Branimira Altgajera iz 1943. godine, gotovo 1000 folksdojčera iz Jugoslavije uspelo je u jesen 1940. da tajno pređe nemačkojugoslovensku granicu i stavi se na raspolaganje nemačkim vlastima. ${ }^{12}$ Mnogi od njih dobiće svoje mesto u nemačkom policijskom aparatu posle okupacije aprila 1941.

${ }^{9}$ Josip Mirnić, Nemci u Bačkoj u Drugom svetskom ratu, Novi Sad 1974, 36-58; M. Ristović, n. d., 97-99. Videti i: Dušan Biber, Nacizem in Nemci v Jugoslaviji 1933-1941, Ljubljana 1966; NOS, II, 92-93, 99, 204, 440. - Folksdojčeri su bili i pouzdan oslonac nemačkim obaveštajnim službama u Jugoslaviji. Uz njihovu pomoć organizovane su tajne radio-stanice, na njih se oslanjala tajna diverzantska grupa „Jupiter“, a iz Rumunije i Mađarske im je stizalo oružje; Isto, passim; NOS, knj. V, 371-379, 558-560.

${ }^{10}$ Branko Bešlin, Vesnik tragedije. Nemačka štampa u Vojvodini 1933-1941. godine, Novi Sad-Sremski Karlovci 2001, 35-37; Vojni arhiv, Beograd (dalje: VA), mikrofilm London, 2, H 298073-H 298116, Državni sekretar dr. Štukart (Stuckart) poslaniku Riteru (Ritter), Berlin 15. jula 1941, Memorandum o položaju Nemstva u oblastima bivše jugoslovenske države. Videti i: M. Ristović, Nemački 'novi poredak' i jugoistočna Evropa, 101-103.

${ }_{11}$ Дан, 31. март 1936, prema: Učitelji iz Nemačke u Vojvodini, Židov, br. 14, 3. april 1936; J. Mirnić, Nemci u Bačkoj, 59-61.

${ }^{12}$ NOS, knj. II, 261. 
Odmah po donošenju odluke da se napadne Jugoslavija, krajem marta 1941. pojavilo se pitanje forme u kojoj će nemački policijski organi delovati na jugoslovenskoj teritoriji. Za to je upotrebljen već ustaljen organizacioni oblik posebnih operativnih jedinica. To je bila Operativna grupa Policije bezbednosti i Službe bezbednosti (Einsatzgruppe der Sipo und des SD, skraćeno: EG). Ona se delila na niže organizacione jedinice, Operativne komande Policije bezbednosti i Službe bezbednosti (Einsatzkommando der Sipo und des SD, skraćeno: EK), koje su vršile aktivnu obaveštajnu i egzekutivnu delatnost. Njihov zadatak je bio da prate jedinice Vermahta i obavljaju policijsko-bezbednosne zadatke. Prvih dana aprila 1941. po naređenju Rajnharda Hajdriha formirana je Operativna grupa Policije bezbednosti i Službe bezbednosti za Jugoslaviju (Einsatzgruppe der Sipo und des SD fuer Jugoslawien, skraćeno: EG Jugoslawien) sastavljena od oko 80 policajaca, koja je okupljena u Beču. Sam Hajdrih je na čelo ove grupe postavio SS-pukovnika Vilhelma Fuksa (Wilchelm Fuchs). Grupa se u Gracu javila generalu Vajksu, a zatim je krenula za jedinicama 2. armije posle početka invazije na Jugoslaviju 6. aprila 1941.

Kao i za druge zemlje prema kojima je delovala obaveštajna služba, u okviru Uprave VI RSHA vođena je kartoteka neprijatelja Rajha u Jugoslaviji. Rukovodilac referata za Jugoslaviju, Bajsner, uoči rata je predao kartoteku Upravi IV (Gestapo), koja će dobiti glavnu ulogu u nemačkom policijsko-bezbednosnom aparatu u Jugoslaviji. Prema toj kartoteci, u Gestapou je sastavljen „Vanredni spisak poternica za Jugoslaviju“ (Sonderfahndungsliste Jugoslawien) od preko 3.000 lica, prema kome su vršena hapšenja po ulasku nemačkih trupa u Jugoslaviju, naročito u Beogradu i Zagrebu. Bajsner je već pre invazije boravio u Zagrebu i stvorio obaveštajnu mrežu i samo formalno je bio podređen Operativnoj grupi policije, odnosno Fuksu. ${ }^{13}$

U skladu sa osnovnim nemačkim antisrpskim stavom i Hitlerovim Privremenim smernicama za podelu zauzete jugoslovenske teritorije od 12. aprila 1941. stvorene su osnove za teritorijalno uobličavanje „novog poretka“ u Jugoslaviji. Nove granice i linija razgraničenja interesnih sfera Nemačke i Italije utvrđeni su na pregovorima ministara inostranih poslova Ribentropa i Ćana u Beču 21. i 22. aprila 1941. Ovom podelom su politički i vojni razlozi potisnuli privredne, jer je razbijanje jugoslovenskog državnog prostora bilo protiv privrednih interesa Trećeg rajha. Nemačka strana je na bečkim pregovorima obezbedila svoj dominantan uticaj. ${ }^{14}$

Dogovorom između Nemačke i Italije podeljena je jugoslovenska državna teritorija, a izvršeno je i razgraničenje zona interesa linijom koja je delila ze-

${ }^{13}$ NOS, knj. II, 391; Isto, knj. IV, 116-117, 230-231. U pripremi spiska za hapšenje učestvovao je i Institut za Jugoistočnu Evropu iz Graca (Suedosteuropa Institut); Der Process gegen die Hauptkriegsverbrecher vor dem Internationalen Militaergericht, Nuernberg, 11. November 1945-1. Oktober 1946, knj. 22, 399 (dalje: Der Process).

${ }^{14}$ M. Ristović, Nemački 'novi poredak' i jugoistočna Evropa, 308-315; D. Lukač, Treći Rajh i zemlje jugoistočne Evrope, knj. III, 20-21. 
mlju pravcem severozapad-jugoistok. Severni deo slovenačkih zemalja, odnosno južni delovi istorijskih austrijskih pokrajina Štajerske i Kranjske, anektirani su Nemačkoj ${ }^{15}$ i predviđeni su za germanizaciju. Preostali deo sa Ljubljanom je priključen Italiji, kao i deo jadranske obale. Italijanske trupe su okupirale veliki deo jadranske obale i zaleđa, kao i Crnu Goru. Italijanskom protektoratu Velikoj Albaniji priključeni su Metohija, veći deo Kosova i zapadna Makedonija. Mađarskoj su pripali Bačka, Baranja, Međumurje i Prekomurje. Najveći deo Makedonije i jugoistočna Srbija pripali su Bugarskoj. „Stara Srbija“ sa severnim Kosovom i Banatom stavljena je pod nemačku vojnu upravu. Od središnjeg dela Jugoslavije - Hrvatske, Slavonije, Srema, Bosne i Hercegovine, Hrvatskog primorja i dela Dalmacije stvorena je Velika Hrvatska pod imenom Nezavisna Država Hrvatska. Ova država je, uz Slovačku, bila „čist“ proizvod „novog evropskog poretka“, odnosno sporazuma nosilaca ovog poretka Nemačke i Italije. ${ }^{16}$

Posle okupacije i podele Jugoslavije, nad većim delom današnje teritorije Srbije uspostavljen je nemački vojnookupacioni režim na čelu sa nemačkim generalom. Ovaj deo Srbije bio je jedina jugoslovenska oblast pod direktnom nemačkom okupacionom upravom, izuzev severnog dela Slovenije koji je anektiran samoj Nemačkoj i na kojem je vršena sistematska germanizacija. Na mestu vojnoupravnog zapovednika Srbije smenjivali su se generali Ferster, Šreder, Dankelman i od decembra 1941. general Bader. Oni su kao svoje glavne poluge vlasti imali pod sobom Komandni štab za vojna pitanja i Upravni štab za pitanja organizacije vlasti.

Iza vojnih jedinica u Jugoslaviju je došla Operativna grupa Policije bezbednosti i službe bezbednosti za Jugoslaviju (Einsatzgruppe Sipo und SD fuer Jugoslawien, skraćeno: EG Jugoslawien). Iz njenog sastava formirana je Operativna komanda Policije bezbednosti i Službe bezbednosti u Zagrebu na čelu sa Bajsnerom, a ostali iz grupe su produžili za Beograd. Do 17. aprila u Beogradu su se prikupili svi preostali pripadnici Operativne grupe policije. Tog dana u Beograd je doputovao SS-general R. Hajdrih i odražao konferenciju na kojoj je dao glavne smernice za rad. Operativna grupa je ubrzo svoju delatnost svela na okupiranu Srbiju i bila je pre svega direktivna i nadzorna ustanova. U Beogradu je odmah formirana i Operativna komanda policije koja je obavljala pretežno operativnoegzekutivne funkcije. Operativne komande će biti raspoređene u Srbiji, ali i u drugim delovima Jugoslavije za koje je Nemačka imala najveći interes. ${ }^{17}$

$\mathrm{Na}$ čelu Operativne grupe policije bio je SS-pukovnik dr Vilhelm Fuks, dok je na čelu njene četvrte uprave (Gestapoa) bio SS-major Hans Helm, do rata

${ }^{15}$ Prema tajnom Hitlerovom dekretu od 7. oktobra 1939. kojim je rajhsfirer SS-a Himler postavljen za komesara Rajha za jačanje nemačke narodnosti, pomenute oblasti bile su jedine jugoslovenske oblasti predviđene za germanizaciju, što je počelo da se sprovodi odmah posle nemačke okupacije; AJ, 110-30-43 do 44, Pregled obaveštenja, br. 15, 22. novembar 1944, Preseljavanje (Umsiedlung), izvod iz Basic Handbook for Germany, glava II, 1944.

${ }^{16}$ Isto.

${ }^{17}$ AJ, 110-583-13, Zapisnik saslušanja dr Vilhelma Fuksa; NOS, knj. IV, 393-394. 
policijski ataše u Beogradu. Iako formalno podređena vojnoupravnom komandantu Srbije, Operativna grupa je bila direktno podređena RSHA u Berlinu. Ipak, šef Upravnog štaba Vojnog zapovednika Srbije državni savetnik SS-general dr Harald Turner uspeo je da kod Hajdriha izdejstvuje da Operativna grupa policije bude delimično i njemu lično odgovorna, s obzirom na njegov čin u SS-u.

Operativna komanda policije (Einsatzkommando der Sipo und des SD) u Beogradu (dalje skraćeno EK Beograd) na čelu sa Karlom Krausom bila je podređena Operativnoj grupi za Jugoslaviju (dalje skraćeno: EG) kao njen organ. Međutim, u tekućim poslovima (poternice, hapšenja) EK Beograd je neposredno opštila sa Upravom IV RSHA u Berlinu obaveštavajući o tome Operativnu grupu. EK Beograd je direktno opštila i sa svim drugim okupacionim ustanovama uz obaveštavanje EG, ali je pri tome ispoljavala sve veću samostalnost. Naravno, među njima je održavan stalan kontakt i stalan lični dodir Fuksa i Krausa. Razlika između EG i EK bila je uglavnom u tome što je EG predstavljala višu i donekle nadzornu i direktivnu, a EK nižu i pretežno egzekutivnu ustanovu. Krajem oktobra 1941. ove dve ustanove praktično su spojene u jedno nadleštvo. I do tada pojedini pripadnici EG vodili su istovremeno poslove u svojoj nadležnosti u EK.

$\mathrm{Na}$ čelu EG bio je njen šef Vilhelm Fuks. Rukovodilac personalnog i administrativnog sektora (prema šemi RSHA uprave I i II) bio je SS-poručnik Valter, zatim SS-kapetan Karl Heler koji su iste poslove obavljali i u EK Beograd. Rukovodilac sektora III (SD) bio je do kraja jula 1941. SS-major Fridrih Polte, a zatim do ukidanja EG SS-potpukovnik Ludvig Tajhman. Rukovodilac sektora IV (Gestapo) sve vreme postojanja EG bio je SS-major Hans Helm. U EG nisu postojali sektori V (Kripo) niti sektor VI kao posebno odeljenje. Po toj liniji radio je rukovodilac sektora III Polte, a zatim SS-major Nasenštajn, koji je vodio isti sektor i u EK Beograd. On je inače bio pripadnik Uprave VI RSHA. Tako je u Srbiji težište obaveštajnog rada sa sektora VI prebačeno potpuno na sektore III i IV.

Personal EG bio je relativno malobrojan, sa oko 25 pripadnika, od toga 11 oficira. Osim Fuksa, najznačajnija ličnost u EG bio je Hans Helm, koji je imao podršku samog šefa Uprave IV (Gestapo) Hajnriha Milera i bio je odličan poznavalac prilika u Srbiji. EG je odlično sarađivala sa ostalim okupacionim ustanovama, kao i sa jedinicama Vermahta i vojnoobaveštajnom službom (Abverom). U EK najznačajniju ulogu imao je Karl Kraus. Helm i Krus su davali pečat policijsko-obaveštajnom radu u okupiranoj Srbiji.

Operativni i egzekutivni organ nemačke policije u Srbiji bila je Operativna komanda Policije bezbednosti i Službe bezbednosti na čelu sa SS-majorom Karlom Krausom, ali je ona tek avgusta 1941. dobila svoju završnu formu koja je odgovarala osnovnoj šemi RSHA. Glavna delatnost bila je koncentrisana na sektor IV (Gestapo) koji je organizaciono bio podeljen na šest odseka: suzbijanje protivnika, prijem prijava, obrada i korišćenje, leteći komando, potere i jevrejski odsek. U prvoj polovini avgusta EK je dobila određenu formu prema šemi RSHA. Na čelu je i dalje bio Karl Kraus, a pomoćnik mu je bio SS-major Karl Hince (Hintze). Sedište nemačkih policijskih službi prvih meseci okupacije je bi- 
lo u zgradi Ministarstva pravde u Ulici kralja Milana da bi posle nekoliko meseci bilo premešteno u Ratnički dom.

Odeljenje I i II (personal i administracija), rukovodilac SS-poručnik Valter (Walter), posle njega SS-kapetan Hans Heler (Heller); Odeljenje III (SD), rukovodilac SS-kapetan dr Gode, koji j istovremeno vodio i referat III A (pravo, administrativno ustrojstvo, unutrašnji politički problemi) uz saradnju tumača Dimitrija Markova. Referat III B (nacionalna pitanja, zdravstvo) vodio je SS-podoficir Hans Bok (Boock ili Bock). Referat III C (nauka, kultura, umetnost, nauka) vodio je SS-potporučnik, kasnije SS-poručnik Hajnc Šreter (Heinz Schroeter). Referat III D (privreda) vodio je SS-poručnik, kasnije SS-kapetan Jozef Hajnčel (Josef Heintschel). U odnosu na uobičajenu šemu, EK Beograd imao je još dva referata: III E koji se bavio raznim emigracijama i manjinama na čelu sa SS-podoficirom Hansom Bokom i referat III F koji je obrađivao crkvena pitanja. Na njegovom čelu bio je SS-poručnik Georg Majr (Mayr). Referat III E je posle nekoliko meseci spojen sa referatom III B.

Odeljenje IV (Gestapo) bavilo se suzbijanjem političkih protivnika i organizovanjem i upravljanjem obaveštajnom službom. U tome pravcu ga je vodio je SS-major Karl Hince, ujedno i zamenik rukovodioca EK Karla Krausa. Njegov zamenik je bio SS-kapetan Ginter Hauzding (Guenther Hausding). Ovo odeljenje je obuhvatalo sledeće referate: IV A - suzbijanje komunizma i marksističkih pokreta, naročito NOP i KPJ, rukovodilac SS-poručnik Erih Vineke (Erich Wienecke). IV B - suzbijanje partizana i pokreta Draže Mihailovića, takođe pod rukovodstvom Vinekea; IV C - potere, administracija po pitanju hapšenika zatvora, logora, transporta, spiskova za streljanja u odmazdama, vođenje centralne kartoteke, referent SS-poručnik Georg Cape (Zappe), a zamenik mu je bio SS-poručnik Švarc (Schwarz); IV D - Jevreji i masoni, rukovodilac SS-potporučnik Fric Štrake (Fritz Stracke), a zamenik SS-potporučnik Hans Šlut (Hans Schlutt); IV E - suzbijanje špijunaže, sabotaže, pitanje pasoša, propusnica i slično, kontrola stranaca, cenzura pošte, provere, rukovodilac SS-poručnik Gerhard Hibner (Gerhard Huebner), zamenik SS-potporučnik Zajdl (Seidel), posle njega SS-potporučnik Fridrih Šubert (Friedrich Schubert). Na sektoru VI radili su sam Karl Kraus, SS-major Nasenštajn i SS-poručnik Erih Gol (Erich Goll).

Uz malo izuzetaka, personal EK je bio nedorastao svom zadatku. To je mahom bilo mlađe i često neiskusno osoblje iz Nemačke sa nižim funkcijama. Postavilo se i pitanje tumača, koje je bilo teško kao i za ostale nemačke ustanove u Srbiji. Kod EG i EK tumači su prvenstveno bili domaći Nemci (folksdojčeri) koji često nisu dovoljno vladali nemačkim jezikom, a i znanje srpskog jezika im je često bilo ograničeno. U celini, sa vrlo malo izuzetaka, kvalitet tumača je bio takav da niukoliko nije mogao da obezbedi adekvatno prevođenje sa jednog jezik na drugi. Pri tome je uloga tumača bila mnogo veća nego što je to odgovaralo njihovoj tehničkoj funkciji i uveliko je premašivala njihov stručni i intelektualni domet. Silom prilika tumač se pojavljivao kao prvi i najbliži saradnik aparata Sipo i $\mathrm{SD}$ u odnosima sa stanovništvom. Tumači su istovremeno organizovali agenture i 
održavali veze između Sipo i SD i agenata. Oni su često privodili agente, pa i upravljali u pojedinostima njihovim radom. Tumači su korišćeni i za neke zadatke koji nisu imali veze sa prevođenjem i organizovanjem agenata, a zahtevali su poznavanje srpskog jezika. Upotrebljavani su kao stražari kod specijalno važnih zatvorenika ili interniraca, na primer kod patrijarha Srpske pravoslavne crkve Gavrila Dožića. ${ }^{18}$ Kao nadređena ustanova, EK je usko sarađivala sa srpskom kvislinškom policijom, odnosno sa Upravom grada Beograda i Specijalnom policijom. ${ }^{19}$

Težište rada EK bilo je preko odeljenja IV (Gestapoa) i njime se bavio gotovo celokupan personal EK. U svome radu EK je najviše koristila mere masovnog zastrašivanja, hapšenja i pogubljenja. Oktobra 1941, EG i EK su fuzionisani i od tada je postojala jedna ustanova pod nazivom Operativna grupa Policije bezbednosti i službe bezbednosti (EG).

Početkom 1942. došlo je do reorganizacije policije u okupiranoj Srbiji. Hitlerovim ukazom od 22. januara 1942. formirano je nadleštvo Višeg vođe SS-a i policije (Hoehere SS- und Polizeifuehrer). Na to mesto je postavljen SS-general August Majsner (Meyszner), dotadašnji zapovednik Policije poretka u okupiranoj Norveškoj. U njegovoj nadležnosti stajali su svi poslovi iz domena Rajhsfirera SS-a, odnosno sve policijske i obaveštajne službe, kao i funkcija Komesara za učvršćivanje nemačke narodnosti (Kommissar fuer die Festigung des Deutschutms). U tom svojstvu, kao i u svojstvu komandanta SS-a on je od Hitlera i Himlera dobio zadatak da od folksdojčera iz Srbije formira jednu SS-diviziju. Do jeseni 1942. on je od banatskih i beogradskih Nemaca formirao 7. SS dobrovoljačku brdsku diviziju „Princ Ojgen“ (Prinz Eugen), koja je bila jedna od najzloglasnijih nemačkih vojnih jedinica. Njegovim dolaskom uspostavljen je mnogo oštriji policijski okupacioni režim koji je pod neposrednom kontrolom držao sve kvislinške ustanove. Sam Majsner, koji je kao i većina ljudstva okupacionih ustanova bio austrijski Nemac, bio je veliki neprijatelj srpskog naroda i zalagao se za najoštrije mere pri gušenju svakog oblika otpora. ${ }^{20}$

Pod komandom Majsnera stajale su dve ustanove - Zapovednik Policije poretka (Befehlshaber der Ordnungspolizei, skraćeno: BdO) i Zapovednik Policije bezbednosti i Službe bezbednosti (Befehlshaber der Sicherheitspolizei und des Sicherheitsdienst, skraćeno: BdS). Na čelu prve, zadužene za opštu policijsku službu bio je SS-pukovnik Andreas Maj (May), dok je na čelu druge, koja je objedinjavala celokupan policijsko-bezbednosni sektor bio SS-pukovnik Emanuel Šefer (Schaefer). Iako pod komandom Majsnera, i Zapovednik Policije poretka (BdO) i Zapovednik Sipo i SD (BdS) bili su istovremeno podređeni i svojim cen-

\footnotetext{
${ }^{18}$ NOS, knj. IV, 420-421.

${ }^{19}$ Бранислав Божовић, Специјална полиција у Београду 1941-1944, Београд 2003, $16,36-47$.

${ }^{20}$ Bojan B. Dimitrijević, General SS i policije August Majsner i srpski sistem bezbednosti 1942-1943, Istorija 20. veka, 3, 2010, 69-82.
} 
tralnim ustanovama u Berlinu. Šefer je na osnovu izveštaja podređenih svakog dana lično podnosio referat Majsneru.

BdS je zamenio ukinutu EG u drugoj polovini januara 1942, kada su Beograd napustili Kraus i Helm, a na dužnost stupio SS-pukovnik Emanuel Šefer. Personal njegove ustanove je ojačan i brojno i kvalitetno tako da je dostigao oko 700 ljudi, od kojih je 300 bilo u Beogradu. Konačna organizacija BdS-a izvršena je u junu 1942. i uglavnom je odgovarala organizacionoj strukturi RSHA, a takva je ostala do kraja okupacije.

U užem štabu BdS-a bio je i SS-potpukovnik Ludvig Tajhman (Ludwig Teichmann) koji je sastavljao dnevne raporte za Višeg vođu SS-a i policije Majsnera. Svog šefa Šefera je obaveštavao o svim važnijim predmetima, koordinisao je rad odeljenja i zamenjivao šefa u svim obavezama koje nisu bile od prvorazrednog značaja. Struktura BdS-a bila je sledeća:

Odeljenja I i II (personal i administracija) vođena su i dalje u personalnoj uniji i vodio ih je SS-kapetan Karl Heler (Heller). Odeljenje I bilo je nadležno za pitanja izgradnje i organizacije nadleštva i za sva personalna pitanja. Odeljenje II bilo je nadležno za celokupno novčano poslovanje, za intendantsko poslovanje, rukovanje zaplenjenim stvarima, obavljanje poslova u vezi sa zaplenjenom jevrejskom imovinom, nadzor nad radionicama i za radiografsku službu i telefonske i teleprinterske veze. Ovde je ukupno bilo 9 referata. Među njima bili su i sledeći:

II A 5 bio je zadužen za upravljanje imovinom zaplenjenom od Srba i Jevreja, o čemu je vođena posebna kartoteka. U ovom odseku registruju se i svi „preseljeni“ odnosno ubijeni koji su za sobom ostavili ma kakav predmet koji su imali pri hapšenju; II C $\mathbf{1}$ bio je zadužen za kartoteku zaplenjenih jevrejskih stanova i nameštaja u njima; II C $\mathbf{2}$ - odsek nabavnog materijala za kancelarije i za lične potrebe personala; II C $\mathbf{3}$ - zadužen za smeštaj pridošlih pripadnika SS-a u Beograd; II C 10 - Blagajna; II D 1 i 2 - radio, telegram, telefonske centrale; II D 3 - Garaža.

Odeljenje III (SD), na čelu je bio SS-major Hans Reksajzen (Rexeisen). Jula 1943. zamenio ga je SS-poručnik, kasnije SS-kapetan Jozef Hajnčel (Josef Heintschel). O radu ovog odeljenja posebno je brinuo Šeferov zamenik Ludvig Tajhman. Personal referata ostao je uglavnom isti kao i u EG.

Odeljenje IV (Gestapo), koje je radilo na suzbijanju političkih protivnika i organizovanju obaveštajne službe protiv njih, vodio je SS-major Bruno Zatler (Sattler). ${ }^{21}$ Referati: IV A 1 - suzbijanje komunizma i levičarskih pokreta, borba protiv NOP-a, saradnja sa Specijalnom policijom, proučavanje levičarskih struja i programa. Referat je imao razgranatu mrežu ispostava na terenu. Na čelu je do juna 1943. bio SS-kapetan Beno Ditges koga je zamenio SS-kapetan Hans Šrader. IV A 2 - ostali levičarski pokreti, odbrana od sabotaža, suzbijanje preno-

${ }^{21} \mathrm{O}$ Zatleru šire u istraživačko-autobiografskoj knjizi njegove kćerke: Beate Niemann, Mein guter Vater. Mein Leben mit seiner Vergangenheit. Eine Taeter-Biographie, Teetz 2005. 
šenja aktivnosti komunista susednih zemalja u Srbiju. Referat je bio u personalnoj uniji sa referatom IV A 1. IV A 3 - obrada pokreta Draže Mihailovića. Ovom problemu posvećivana je velika pažnja jer se DM smatrao eksponentom britanske politike, a pri obradi ovog problema Nemci nisu imali poverenje u kvislinšku policiju. Kada je reč o borbi protiv NOP-a kvislinškoj policiji je poklanjano puno poverenje tako da je deo delatnosti referata IV A 1 prenet na Specijalnu policiju. Odsek je vodio SS-kapetan Hajnrih Brant, a zamenik mu je bio SS-poručnik Fric Everding. IV A 4 - sprovođenje zaštitnih mera za obezbeđenje rukovodilaca, rad sa emigracijom. Rukovodilac SS-kapetan Ditges, zatim SS-kapetan Šrater. ${ }^{22}$

Referati IV B 1 (crkve, sekte) i IV B 2 nisu postojali u okviru beogradskog BdS-a, što bi bilo u skladu sa šemom RSHA. Iz posebnih razloga crkve su obrađivane u okviru odeljenja III (SD). Referati IV B 3 (masoni) i IV B 4 (Jevreji) vođeni su u personalnoj uniji, a vodili su ih SS-potporučnik Fric Štrake, do novembra 1942; SS-poručnik Hans Šlut do februara 1943; SS-potporučnik Vili Boden, do septembra 1943. Tada su ovi referati pridruženi referatu IV D pošto su Jevreji praktično bili likvidirani, a masonima nije posvećivana pažnja. Ovi referati su bili zaduženi i za političko-policijsko proveravanje udruženja i društava i za odobravanje njihovog osnivanja.

IV C 1 - akcije protiv političkih protivnika van stranaka ili organizacija, veza sa poštanskom cenzurom, pasoši i propusnice, kontrola stranaca, provere sumnjivih. Rukovodilac SS-potporučnik, kasnije SS-poručnik Georg Cape. Referat je vođen u personalnoj uniji sa referatima IV D (strani radnici, stranci sa neprijateljskim stavom i ruska emigracija), IV E 1 (odbrana od špijunaže i sabotaže, zaštita postrojenja, proveravanje radnika i nameštenika u njima) i IV E 3 (opšta politička i policijska provera po raznim traženjima). IV C 2 je bio referat za takozvani „zaštitni zatvor“ (Schutzhaft), zatvore i logore. U njegovu nadležnost spadalo je sve u vezi sa tim domenom, a još i izvršenje smrtnih presuda preko suda BdS-a i vođenje centralne kartoteke uhapšenih lica i spiskova svih vrsta. Referat je bio nadležan i za sastavljanje spiskova lica nad kojima je trebalo da se izvrši odmazda, ili koja treba da budu upućena na prinudni rad ili u koncentracione logore na osnovu odluka nadležnih referata. $\mathrm{Na}$ čelu referata do septembra 1942. bio je SS-podoficir Karl Lederer, zatim do februara 1944. SS-podoficir Paul Rajcig (Reitzig), a posle njega SS-podoficir Erih Tolkin (Erich Tollkuehn).

Odeljenje V, kriminalno. Formirano je 1942 i na čelu mu je bio SS-kapetan, kasnije SS-major Bert Gorbant. Personal je bio mali jer je ove poslove uglavnom obavljala srpska Specijalna policija.

${ }^{22}$ NOS, knj. IV, 631. Videti i izveštaj agenta organizacije D. Mihailovića „Augusta“ s početka oktobra 1943; Венцеслав Глишић, Терор и злочини нацистичке Немачке у Србији 19411944, Београд 1970, Прилог бр. 4, 263-274. O „Augustu“, odnosno Borislavu Mesaroviću videti: Б. Божовић, Специјална полииија у Београду, 251, 273: Сима Ц. Ћирковић, Ко је ко у Недићевој Србији 1941-1944. Лексикон личности. Слика једне забрањене епохе, Београд 2009, 320 321. 
Odeljenje VI, obaveštajna služba prema inostranstvu, do jeseni 1942. vodio je SS-poručnik Gol, zatim SS-kapetan Ginter Hauzding, od sredine 1943. SS-major Reksajzen.

U okviru BdS-a postojala je i stražarska četa sastavljena od folksdojčera koja je obavljala poslove zaštite zgrade BdS-a (Ratnički dom, danas Centralni dom Vojske Srbije, ulica Braće Jugovića 19) i vršila je stražarsku službu. Podoficiri i oficiri komandnog sastava čete bili su iz sastava SS-a. Ova stražarska četa je davala ljudstvo i za čuvanje zatvora BdS-a i transporta uhapšenika, učestvovala je u hapšenjima, pretresima i racijama, a od kraja 1943. obezbeđivala je logor na Banjici. Stražarskom četom je do kraja 1942. komandovao SS-potporučnik Kemena, do sredine 1943. SS-potporučnik Vinter, a zatim drugi.

BdS je imao tri svoja zatvora. Prvi je bio policijski zatvor (Polizeigefaengnis) u zgradi Okružnog suda za Beogradski okrug, ulica Kralja Aleksandra 5 (danas Trg Nikole Pašića). U samoj zgradi BdS-a u zgradi Ratničkog doma postojao je zatvor u podrumskim prostorijama (Hausgefaengnis). U istoj zgradi bio je i takozvani „počasni zatvor“ (Ehrenhaft), poseban stan za uhapšenike prema kojima su postojali posebni obziri, kakvi su bili četnički komandanti Jezdimir Dangić i Pavle Đurišić.

Zatvorenici BdS-a držani su i u nemačkom delu logora na Banjici, u Jevrejskom logoru na beogradskoj Autokomandi (Topovske šupe) i u logoru na Beogradskom sajmištu. Iz sastava BdS-a formirane su posebne komande (Sonderkommando) koje su upravljale ovim logorima. Logori u Šapcu, Nišu i Zaječaru (kraće vreme 1943) i Velikom Bečkereku (danas: Zrenjanin) bile su pod upravom lokalnih ispostava BdS-a. Iz ovih logora zatvorenici su odvođeni na streljanje u odmazdama ili su upućivani u dva beogradska logora, a odatle u nemačke koncentracione i radne logore u samoj Nemačkoj ili u okupiranim zemljama. Stoga su ovi logori u svom nazivu uglavnom imali oznaku prihvatni logor (Anhaltelager). Međutim, po svojoj organizaciji, a pre svega po masovnom uništenju zatočenika, ovi logori se nisu mnogo razlikovali od koncentracionih logora u Trećem rajhu i okupiranim zemljama. To se pre svega odnosi na logor na Beogradskom sajmištu. ${ }^{23}$ Logori u Topovskim šupama i na Beogradskom sajmištu (prva faza postojanja kada je to bio Jevrejski logor) imali su centralno mesto u sprovođenju „konačnog rešenja jevrejskog pitanja“" u Srbiji. ${ }^{24}$

Istragu u odeljenju IV (Gestapo) vodio je jedan pripadnik nadležnog referata od početka do kraja, najčešće uz mučenje. U policijskoj terminologiji za to je korišćen eufemizam „,pooštreno saslušanje“. Istražitelj je na pojedinim etapama istrage podnosio izveštaje pretpostavljenima i predlagao dodatne mere. Po

${ }^{23}$ Милан Кољанин, Немачки логори у окупационом систему у Југославији (19411944), Други свјетски рат - 50 година касније, зборник радова, Подгорица 1997, 269-288.

${ }_{24}$ M. Koljanin, Nemački logor na Beogradskom sajmištu, 33-40; 127-131; Walter Manoschek, 'Serbien ist judenfrei'. Militaerische Besatzungspolitik und Judenvenichtung in Serbien 1941/42, Muenchen 1993, 169-184. 
okončanju istrage podnosio je završni izveštaj (Abschlussbericht) nadležnom rukovodiocu referata, a zatim šefu odeljenja. U završnom izveštaju su za svako lice navođeni podaci dobijeni istragom, pri čemu je davan i predlog za dalji postupak sa njim. Predlozi su bili sledeći: otpuštanje, puštanje pošto se vreme provedeno u zatvoru može smatrati dovoljnom kaznom, puštanje uz zaplenu robe ili novca, upućivanje na „slobodni rad“ u Nemačku (radni logor), zadržavanje u zatvoru ili logoru na određeno vreme, upućivanje na prinudni rad, upućivanje u koncentracioni logor, upućivanje u logor ratnih zarobljenika, unošenje u spisak za odmazdu. To je značilo da će lice biti streljano prvom prilikom kada bude došlo do napada na okupacione ili kvislinške pripadnike ili na važnije objekte. Za upućivanje u koncentracioni logor bilo je dovoljno mišljenje šefa odeljenja, ponekad i samo šefa nadležnog referata.

Pripadnici BdS-a delili su se u tri kategorije. Prvu su činili stalni činovnici, inače policijski službenici koji su, osim SS-čina, imali i kriminalističko-policijsko ili administrativno-policijsko zvanje. To su gotovo bez izuzetaka bili Nemci iz same Nemačke, a iz njihovih redova regrutovani su rukovodioci odeljenja i referata, stručni službenici, islednici, donekle i pripadnici pomoćno-tehničkog personala. Druga kategorija su bili rezervisti, koji nisu po profesiji bili policijski činovnici nego su dodeljeni BdS-u na rad. Tu su bila lica koja su mobilisana u SS-jedinice (Waffen-SS) i dodeljeni su na rad BdS-u zbog nekih posebnih znanja. Sva lica ove kategorije radila su na pomoćnim poslovima u operativi ili u tehničkim službama. Treća kategorija bila su lica uzeta u službu samog BdS-a i koji su mogli uvek da budu otpušteni. Tu su spadali razni tumači i prevodioci, mahom folksdojčeri, zatim sve službenice nadleštva BdS-a, daktilografkinje i slično. $^{25}$

Zbog znanja jezika folksdojčerski saradnici BdS-a imali su nesrazmerno veliku ulogu u Gestapou u kojem se odlučivalo o životu i smrti, o egzistenciji lica nad kojima je vođena istraga. Uglavnom nedorasli svom poslu, oni su tim više bili nadmeni i prepotentni prema srpskom stanovništvu opterećeni željom da se dokažu pred svojim šefovima, uglavnom Nemcima iz Rajha. Oni su, sa svoje strane, gledali sa visine na te najčešće poluobrazovane domaće Nemce bez kojih ipak nisu mogli da se nose sa svojim zadacima. I sam BdS uglavnom nije bio dorastao svojim zadacima. Nedostatak stručnosti i sposobnosti, BdS je nadoknađivao izuzetnom brutalnošću i bezobzirnošću.

Da bi se to stanje popravilo u okviru BdS-a održavani su razni stručni kursevi, naročito za podizanje opšteg obaveštajnog nivoa prevodilačkog kadra. U proleće 1942. BdS je preko odeljenja III i IV organizovao dvonedeljni kurs za tumače BdS-a iz Beograda i ispostava iz unutrašnjosti o obaveštajnom radu. Kod BdS-a su pripadnici odseka za školovanje Uprave I RSHA iz Berlina održali dva kursa za pripadnike Sipo i SD koji su iz podoficirskog trebali da pređu u oficirski rang.

${ }^{25}$ NOS, knj. IV, 460. 
Zbog brzog napredovanja Crvene armije, evakuacija BDS-a iz Beograda i Srbije počela je već avgusta 1944. kada je u Nemačku prebačen ženski personal. Tada je počelo delimično uništavanje arhive i njeno prebacivanje u Rajh. Pri rukovodećoj ustanovi Gestapoa u Beču organizovana je prihvatna stanica za pripadnike BdS-a odakle su raspoređivani na druge dužnosti. Neki pripadnici BdS-a dobili su vojničke knjižice Vafen-SS prema čemu bi izgledalo da nisu pripadali Sipo i SD. To je bila samo kamuflaža folksdojčera kojima je objašnjeno da u slučaju zarobljavanja pokažu ove knjižice i ne otkrivaju da su bili u policijsko-bezbednosnom aparatu. Evakuacija iz Beograda vršena je u kolonama pri čemu je jedan deo nižeg personala ostao u Vilanju (Mađarska), gde je ostala i stražarska četa, a zatim su predati BdS-u u Budimpešti. Sa poslednjim delom ljudstva 5. oktobra 1944. povukao se i šef BdS-a Šefer, takođe u Vilanj gde je izvršio raspored ljudstva. Oko 70 folksdojčera upućeno je u mesto Konic (Konitz) u Poljskoj gde je bilo posebno nastavno odeljenje SS-a za školovanje, neki pripadnici odeljenja IV su upućeni u Budimpeštu, Grac, Maribor ili u Beč gde je formirana kancelarija za likvidaciju BdS-a kojom je on lično rukovodio.

Milan Koljanin

\section{THE STRUCTURE AND ACTIVITIES OF THE NAZI GERMAN POLICE IN OCCUPIED SERBIA 1941-1944}

\section{Summary}

After taking of the political power in Germany by the Hitler and his National socialist party, a huge repressive police apparatus was created. It was one of the main tools for the rebuilding the Germany state and society on the new principles of social organization. By the beginning of 1939, all state and party police branches were subordinated to a Main security department of the State (RSHA). This department took the main repsonsibilities for conducting a occupation strategies in countries conquered by the Third Reich. It was the same practice inside of the occupied Serbia 1941/44. The pivotal place in police branches was taken by the RSHA's $4^{\text {th }}$ section, the Gestapo. Those services have the main executive role in organising the mass reprisals over the population, focusing on real or imagined enemies. Sometimes helped by the Serbian quisling apparatus. This help was especially needed in suppressing the communist movement. On the other side, combating the royalist resistance movement headed by the General Draža Mihailović was matter of exclusive Nazi structure, excluding the local Serbian authorities. By the end of January 1942, German Police structure in Serbia was reorganized. The whole system was enlarged, and level of the conducted repression became much more harsh. This organization remained until the end of the Nazi German occupation of Serbia in October 1944. 